\title{
First report of Aspergillus europaeus causing postharvest bulb rot of garlic in Italy
}

\author{
Alice Spadoni $^{1} \cdot$ Antonio Ippolito $^{2} \cdot$ Naouel Admane ${ }^{1} \cdot$ Simona M. Sanzani ${ }^{1}$ \\ Received: 16 December 2019 / Accepted: 31 December 2019 / Published online: 3 January 2020 \\ (C) Società Italiana di Patologia Vegetale (S.I.Pa.V.) 2020
}

Keywords Aspergillus europaeus $\cdot$ Allium sativum $\cdot$ Calmodulin gene $\cdot$ Bulb rot

In 2019, landrace garlic bulbs (Allium sativum L.) showing brown, water-soaking lesions often covered by yellowish mould, were obtained from a storehouse of Foggia province, southern Italy. The symptoms were observed on $30 \%$ of stored bulbs. Surface-sterilized rotted portions were plated on PDA containing streptomycin and ampicillin $(250 \mathrm{mg} / \mathrm{L}$ each $)$, incubated at $24 \pm 1{ }^{\circ} \mathrm{C}$ in the dark, and sub-cultured on MEA. After 7 day-incubation, colonies were $23-30 \mathrm{~mm}$, plane, floccose, eventually with a raised centre; mycelium was yellowish-white to grey, and sporulation in the colony centre was strong yellow to light olive brown; a slightly pronounced light to vivid yellow soluble pigment was released in the medium. Vesicle was pyriform or globose, biseriate; metulae broadening toward the top, usually 6-25 $\times 5-9 \mu \mathrm{m}$, covering $3 / 4$ to entire vesicle; phialides ampulliform, 6-11.5 $\times 3-6 \mu \mathrm{m}$; conidia were $3.5-5 \times 3-4.5 \mu \mathrm{m}$, colourless, globose or subglobose, coarsely roughened and yellow-brown to brown at maturity. Those characteristics identified the fungus as Aspergillus europaeus (Hubka et al. 2016). For confirmation , DNA of a representative isolate was amplified using primers CMD5/CMD6 (Samson et al. 2014). The amplicon (GenBank accession No. MN792638) showed $100 \%$ identity with another A. europaeus sequence (LN909007). The strain FV3 was deposited in the fungal collection at CIHEAM Bari (Italy). For pathogenicity tests, surface-sterilized garlic cloves were pin- prick-inoculated with 100 conidia of A. europaeus. Sterile distilled water was used as an uninoculated control. After 7 days at $25 \pm 1{ }^{\circ} \mathrm{C}$, typical symptoms developed only on inoculated bulbs. The re-isolated fungus corresponded to A. europaeus, fulfilling Koch's postulates. To the best of our knowledge A. europaeus have never been described on garlic, and thus this is the first report of A. europaeus causing postharvest rot of garlic bulbs obtained from storage in Italy. Effective control measures need to be adopted to prevent losses during storage and shelf-life

\section{References}

Hubka V, Nováková A, Samson RA, Houbraken J, Frisvad JC, Sklenář F, Varga J, Kolařík M (2016) Aspergillus europaeus sp. nov., a widely distributed soil-borne species related to $A$. wentii (section Cremei). Plant Syst Evol 302(6):641-650

Samson RA, Visagie CM, Houbraken J, Hong SB, Hubka V, Klaassen CHV, Perrone G, Seifert KA, Tanney JB, Varga J, Yaguchi T, Frisvad JC (2014) Phylogeny, identification and nomenclature of the genus Aspergillus. Stud Mycol 78:141-173

Publisher's note Springer Nature remains neutral with regard to jurisdictional claims in published maps and institutional affiliations.
Simona M. Sanzani

sanzani@iamb.it

CIHEAM Bari, Via Ceglie 9, 70010 Valenzano (BA), Italy

2 Dipartimento di Scienze del Suolo, della Pianta e degli Alimenti, Università degli Studi di Bari Aldo Moro, Via Amendola 165/A, 70126 Bari, Italy 